\title{
Introduction to the Open Economies Review Special Issue on "Monetary Policy, Exchange Rates and Integration"
}

\author{
Ansgar Belke ${ }^{1}$
}

Published online: 23 September 2017

(C) Springer Science+Business Media, LLC 2017

From June 16 to 19, 2016, the European Economics and Finance Society (EEFS) hosted its fifteenth Annual Conference in Amsterdam in collaboration with Open Economies Review. A peer-reviewed selection of the papers on the topic "Monetary Policy, Exchange rates and Integration" presented at the conference, is included in this issue.

The special issue starts with two papers on central bank issues. The first one by Benoit Cœuré deals with "Central bank communication in a low interest rate environment." The author starts from the observation that the relationship of central banks with the outside world has evolved considerably over the years. Using the ECB's experience, Cœuré focuses on the functional dimension underlying the increased importance of communication for central banks in a low interest rate environment that derives from the relationship between the monetary authority and financial markets.

In the second paper, "Assessing the impact of ECB Quantitative Easing (QE) on the real economy," Lukas Vogel and Romanos Priftis analyse the macroeconomic effects of the European Central Bank's quantitative easing $(\mathrm{QE})$ programme. The impact of QE is investigated under the lens of a dynamic macroeconomic model, which includes assets of different types and maturities, and explicitly introduces asset purchases of long-term bonds (held by Eurozone and non-Eurozone residents) by the central bank. With imperfect substitutability between asset classes, QE is financed through enhanced liquidity provision to the private sector and affects the term premium, stock prices, the exchange rate and the private sector's saving decision.

The next cluster of papers deals with monetary union issues, with a specific focus on Europe. In their paper, "EMU stability: Direct and indirect risk sharing", Paolo Canofari, Giovanni Di Bartolomeo and Marcello Messori analyze the effectiveness of different risk-sharing mechanisms in providing stability to a monetary union. For this purpose, they select two stylized tools with extreme and opposite features. The first is

Ansgar Belke

ansgar.belke@uni-due.de

1 Department of Economics, University of Duisburg-Essen, D-45117 Essen, Germany 
an expansionary but conventional monetary policy that is used to help EMU's most fragile member states manage their public debts. The second consists of a centralized fiscal policy that allows for the transfer of a portion of these public debts from EMU's most fragile member states to those considered EMU's core. Using a stylized peripherycore model of a monetary union, the authors compare the strengths and weaknesses of these two tools in order to reach some welfare implications in terms of union stability.

Ansgar Belke, Clemens Domnick and Daniel Gros, in a paper titled "Business cycle synchronization in the EMU: Core vs. periphery," examine business cycle synchronization in the European Monetary Union with a special focus on the coreperiphery pattern in the aftermath of the crisis. Their panel data estimates suggest that it is countries belonging to the core that have experienced increased synchronization among themselves after 2007, whereas peripheral countries underwent decreased synchronization with the core, the non-EMU countries and amongst each other. Correlation coefficients and nonparametric local polynomial regressions corroborate these findings. The authors argue that the usual focus on comovements and correlations might be misleading, since they also find large differences in the amplitude of national cycles.

In her paper, "Economic costs and benefits of EMU membership from the perspective of a non-member," Emilia Gyoerk, focuses on the largest EU economy outside of the euro, Sweden. She applies the novel synthetic control method of estimation to evaluate whether there are costs or benefits associated with EMU membership in terms of various aspects of economic performance and how these have developed from 1999 until 2015. Her findings indicate that Sweden would have borne non-negligible costs from currency union membership, exemplified by lower productivity, exports, investment, and consumption, and bigger government expenditure and imports.

The special issue then continues with two papers indirectly related to EMU, focusing on labor and product market flexibility and political governance structures. Robert Anderton, Arno Hantzsche, Simon Savsek and Máthé Tóth contribute a paper titled "Sectoral wage rigidities and labor and product market institutions in the Euro area." They estimate wage Phillips curve relationships between sectoral wage growth, unemployment, and productivity in a country-industry panel of euro area countries. The authors find that institutional rigidities - such as labor and product market institutions and regulations - limit the adjustment of euro-area wages to unemployment, in both economic upturns and downturns, particularly in the manufacturing sector and, to a lesser extent, in the construction and service sectors. These results are robust to specifications that account for factors that may affect structural unemployment, as well as changes in the skill composition of employment that may affect the evolution of aggregate wages. Their results also hold for panels including or excluding the public sector. The authors find that, from a policy perspective, reforms in product and labor markets which reduce wage rigidities, can facilitate employment growth and enhance the rebalancing process in the euro area.

In the paper, "Voting behavior in the European Parliament and economic governance reform: does nationality matter?", Elisa Cencig and Laura Sabani, analyse members of the European Parliament' (MEPs) voting behavior on all regulations and directives forming the Six-Pack and the Two-Pack, together with 
the key vote required to establish the European Stability Mechanism (ESM). Whereas scholarly work has traditionally shown MEPs' voting behavior to be primarily driven by ideology and more specifically, by the MEPs' party group affiliation, Cencig and Sabani's prior is to find MEPs' national origins to play a counterbalancing role which - at least partially - weakens intra-party position on key economic governance matters, where a conflict of interest might exist between creditor and debtor member countries. The authors' findings confirm that national interests and country-level economic variables can predict MEPs' votes in a considerable number of cases, opening new avenues for future research on territorial cleavages in the European Parliament.

Two papers on exchange rates follow. The first contribution is "The relevance of the monetary model for the Euro / USD exchange rate determination: a long run perspective," by Dimitris Georgoutsos and Georgios Kouretas. This study tries to fill a vacuum in the literature on the relevance of economic fundamentals for the Euro / USD exchange rate determination. The authors adopt the monetary model of the exchange rate determination as their testing vehicle and investigate the relevance of various versions of this model over a long time horizon, spanning the period from the inception of euro till the present time. For this purpose, they rely on cointegration techniques. In accordance with the relevant literature, they fail to accept most of the variants of this model. However, they get encouraging results from an expanded version of the monetary model where demand and productivity factors appear in the set of the exchange rate determinants.

The second paper, "The long-run determination of the real exchange rate; evidence from an intertemporal modelling framework using the dollar-pound exchange rate," written by Keith Pilbeam and Ioannis Litsios, develops a model of optimal choice over an array of different assets, including domestic and foreign bonds, domestic and foreign equities and domestic and foreign real money balances to examine the determination of the real exchange rate in the long-run. The model is tested empirically using data from the UK and the USA. The results show that all the coefficients of the model are correctly signed and significant. Consequently, financial assets may play a significant role in the determination of the real exchange rate.

The special issue concludes with the contribution "Interlinkages between household and corporate debt in advanced economies" by Jean-Charles Bricongne and Aurora Mordonu. The authors contribute to the debate on deleveraging in the non-financial private sector. They propose a framework for assessing the interconnectedness of debt dynamics, in particular deleveraging in the household and in the non-financial corporate sectors, using instrumental techniques for a panel of 36 mostly OECD countries, from 1981 to 2015 . Households' debt developments turn out to be positively associated with non-financial corporations' debt dynamics for the whole sample. Conversely, corporate debt has a positive influence on household debt and in particular during deleveraging episodes and in relatively labor-intensive countries. The authors argue that this result is consistent with the functioning of the income channel in which corporations squeeze their wage bill in order to restore profitability.

The European Economics and Finance Society's (EEFS) fifteenth Annual Conference in Amsterdam provided the great opportunity for participants to gain 
new insights into some highly topical issues. I want to thank George Tavlas, the Editor-in-Chief, for providing me with the opportunity to guest-edit this Special Issue of the Open Economies Review. I am also heavily indebted to the referees of the papers included in this Special Issue, the constructive reports of whom resulted in substantial improvements of the papers published. 